\title{
Re-Envisioning the Fight Against Patriarchy: The Case of South African Women
}

\author{
Tsoaledi Daniel Thobejane
}

Institute for Gender and Youth Studies, University of Venda, South Africa

Daniel.thobejane@univen.ac.za/Thobs46@yahoo.com

\author{
Doi:10.5901/mjss.2014.v5n27p896
}

\begin{abstract}
This paper invokes the almost dormant voices of both men and women; that should speak out against patriarchy especially in the face of the re-awakening scourge of violent crime, rape and domestic violence in South Africa. The paper is motivated by the present statistics that are unfathomably high regarding this scourge. While the struggle against racial Capitalism transcended the binary of race and class, it did not (fully) embrace an anti-patriarchal struggle that was waged by progressive thinkers internationally. Hence we are faced with a situation in which women still play second fiddle in the day to day business of the country(irrespective of the power they wield)today. Some of the radical Feminists and Marxist thinkers in the country also made a political blunder by relying on the fact that once the contradictions (between labour and capital) are ameliorated, then we will have an egalitarian, anti-sexist society. This political blunder gave way to the situation in which patriarchy had ingrained itself into the psyche of the society. The paper therefore argues for a stronger Feminist Movement that will offset women's oppression in patriarchal gender relations, and also posits a more radical transformation of the society rather than relying on the Neo-liberal political agenda of the ruling class.
\end{abstract}

Keywords: Radical Feminism, Black Feminism, Racial Capitalism, Apartheid, Liberation,Egalitarianism.

\section{Introduction}

Domestic violence is a global problem which has no respect for race, economic status or age. It violates the fundamental human rights of those caught up in it and often results in serious injury or death. It has been with us (as a silent predator) for so long now. In a patriarchal society women are subordinated to men, and this, according to Marxist feminists, finds its roots in the historical contradictions between labour and capital. Many studies have been conducted to get to the root causes of domestic violence. In interviews conducted by The Advocates for Human Rights in 2006, it was found that people often discussed domestic violence in terms of race, ethnicity, class, educational level or age of the abuser. Violence in the home setting is rife in most countries. Women are its usual victims while men are the perpetrators. The tradition of patriarchal control of marital decisions and resources gives the man the right to use the ultimate resource like violence to enact that control. It can further be argued that violence against women is perpetrated when legislation, law enforcement and judicial systems condone or do not recognize domestic violence as a crime (Brubaker 1993). According to the Social Science and Medicine organization (2012), South African society is amongst the violent in the world. Apparently, decades of apartheid state- sponsored violence and reactive community insurrection (see Truth and reconciliation, 1991) have contributed to a situation in which for many people physical violence is a first line strategy to resolve conflict. Forms of violence revolve around slapping, threatening to beat, persuading a woman to have sex, hitting with objects, stabbing with a knife, violent rape and assaulting with fists. In South Africa, about 5 women are killed every minute. Also, one woman is raped every minute. This usually happens when a woman rejects a man's proposal to have a relationship and attempts by a woman to end a relationship.

The government has been pro-active in stopping this scourge especially after the democratic dispensation in 1994. Many discriminatory statutes were scrapped. Women have been given reproductive rights (eg.the choice of termination of pregnancy), and the domestic violence Act of 1998 was enacted to stop violence against women.

\section{Broad Definitions of Domestic Violence}

Domestic violence includes violence perpetrated by intimate partners and family members, and is manifested through physical abuse, sexual abuse, psychological abuse and economic abuse (see United Nations Children's Fund, 200:4). It takes place at pre-birth, whereby women engage in abortion because of the discovery that they are pregnant with a baby -girl. Others include female infanticide, physical, sexual and psychological abuse. Domestic violence is a disease 
prevailing in all strata of society. It is present in the lives of both the educated and uneducated; the rich and the poor.

Studies conducted by Ellsberg \& Heise (2008) show that violence against women is endemic around the world and that it erodes women's physical and mental wellbeing; interferes with their productive engagement in society; destroys families; and unravels the very fabric of communities. There is growing evidence that abuse has severe consequences for women's long-term health. The victims of this scourge exhibit more physical symptoms of illness and decreased productivity. Abused women are at increased risk of unwanted pregnancies, miscarriages, sexually transmitted diseases and gynecological problems. Not surprisingly, violence against women is rooted in women's lack of power relative to men and society as a whole. This paper therefore argues that the South African feminist movement must establish a new direction for the $20^{\text {th }}$ century. A feminist movement should strive to conquer sexist oppression and patriarchy. This is the foundation to establish an egalitarian society devoid of sexism and patriarchy.

Domestic violence in this country cannot be tackled until the foundations of capitalist exploitation are totally eradicated. Domestic violence confirms that women are victimized by sexist oppression. According to Hooks (1986), sexism is perpetuated by institutional and social structures, and by individuals who dominate, exploit or oppress; and by the victims themselves who are socialized to behave in ways that make them act in complicity with the status -quo. She further argues that Male supremacist ideology encourages women to believe they are valueless and obtain value only by relating to or bonding with men.

Men in pre and post-apartheid South Africa have benefitted from patriarchy. The political analysis in the struggle for liberation overlooked the pandemic of patriarchy. Though men (especially Black men) were concerned about male oppression and Capitalist exploitation, they subconsciously believed that there are privileges and powers they should possess simply because they were/are male.

The South African Department of Justice estimates that one out of every four South African women is a survivor of domestic violence.An organization called People Opposing Women Abuse (POWA) also estimates that one in every six women who die is killed by an intimate partner (the case of Oscar Pistorius bears testimony to this fact).Furthermore a survey conducted recently has revealed that close to $45 \%$ of women had experienced all forms of abuse. About $60 \%$ of these abuses were committed by partners, lovers or spouses. In 1998, the South African government sought to eradicate the occurrence of domestic violence and abuse by promulgating the Domestic violence Act,116 of 1998. This act strove to afford the victims of domestic violence the maximum protection that the law can provide .Inspite of this, domestic violence continues to spiral out of hand. Individuals who cohabit in domestic relationships continue to endure every moment of ongoing abuse and torture. Domestic violence in South Africa is strongly related to conservative ideas about the position of women. These ideas are as follows:

That a woman should obey her husband

A working woman should give her money to the husband

A man has the final say in family matters

A woman needs her partners' permission to work

If a man beats you he shows that he loves you (Jewkes et al, 2002).

\section{Patriarchy, Mysogyny and the Oppression of Women}

Feminist movements around the world (such as the Liberal feminists, the radical feminists, Marxist feminists, Modernists and post-modernists and post -structuralists alike) speak with one voice when it comes to the de-construction of a patriarchal super-structure that finds its feeding ground in the capitalist mode of production which is leading in the perpetuation of the super-exploitation of the working class in general, and women in particular (Collins 2009).

In this super-structure, female marginalization is seen as a strategic point in furthering a patriarchal agenda. The ideology of the super-structure (which feeds on patriarchy) cannot succeed without the creation of a cheap labour reservoir and the sub-humanization of women by way of reducing them into mere objects of pro-creation and/or reproduction. The ideology imminent in this super-structure always posits men as superior to women, regardless of their (ie. Women) standing in society. It views men as sacrosanct and women as subservient.

Stereotypical ideologies of gender justifies discrimination between the sexes, and the oppression of women. Most of our institutions (including the church) privilege men at the expense of women. The class structure inherent in our society is also highly gendered, wherein women are at the bottom of the ladder. While the South African government has made some strides in the implementation of gender parity between men and women since the Beijing conference, we are yet to see some of its policies translated into action even within the ruling party of the day. It is indeed disheartening to see even some of our educated political activists show-casing a Machista approach. This misogyny begs of us to analyze 
the gendered struggle that feminist movements are waging in this country, and whether we have a truly women's organization that champions the right of women irrespective of political affiliation, religion, class or race. It appears that we need to examine the psycho-social effects of the system of patriarchy even amongst the well-educated masses of our people .During our struggle for liberation, we had powerful women who stood side-by -side with their male counterparts in the struggle to unseat the illegitimate government of the racist minority regime.

While this struggle transcended the binary of race and class, it did not (fully) embrace an anti-patriarchal struggle that was waged internationally. Hence we are faced with a situation in which women still play second fiddle in the day to day business of our country(irrespective of the power they wield)today. Some of the radical and Marxist thinkers in the country also made a political blunder by relying on the fact that once the contradictions (between labour and capital) are ameliorated, we will have an egalitarian, anti-sexist society. They undermined the way in which patriarchy had ingrained itself into the psyche of the society.

\section{Neo-Liberalism and Patriarchy}

The persistence of the harsh conditions in the South African townships and villages proves that neo-liberal policies have failed the destitute and women in particular. The South African state is protective of monopoly capital, which is the evil twin of patriarchal oppression and neo-liberalism. Socializing the means of production may help to stymie the untold suffering our people are undergoing, and to uproot patriarchal practices which are encouraged by capitalism.

\subsection{A brief history on Neo-liberalism.}

Neo-liberalism is a theory and practice that sets itself on a contradictory path with socialism or Marxism. The gluttony and greed by the capitalist order, has seen the country's decline to the worst economic recession since the construction of neoliberal policies by Paul Volcker ${ }^{1}$ and Jimmy Carter as from 1965. These policies have been endorsed by one US President to the other, until President Barrack Obama was left with no option but to urge the congress to pass a bail -out plan, by way of state intervention to the ailing economy, to most banks and companies that were bankrupted by corporate greed and Capitalism.

The US economic crisis of 2009 is not the only stagflation that hit the country recently. This also happened in the 1970's. Today, many countries in the world are experiencing an economic crush or meltdown due to the failed policies of neo-liberalism(or, shall I say, Capitalism).States and governments around the world are forced to intervene by way of economic bail-out plans in order to prop-up the capitalist economic order. For the resuscitation of their markets, they are forced to introduce socialist mechanisms that have been rebuked in capitalist countries.

Neo-liberalism has seen an upsurge in inequalities on wages and salaries around the world. It is argued that the top $1 \%$ of income earners has since doubled with the advent of neoliberalism. In Russia, there was a high polarization of salaries between the poor and rich especially after the announcements of "Perestroika" and Glastnost" policies by Mikael Gorbachev. These inequalities have been repeated in China, Mexico and Eastern European countries. It can be further argued that neoliberalism is only interested in the restoration of power to the smallest economic elites around the world. In explaining what neoliberalism entails, Harvey $(2007)^{2}$ asserts that it is a Utopian project to realize a theoretical design for the reorganization of international capitalism or a political project to re-establish the conditions for capital accumulation and to restore the power of economic elites(Harvey 2007:19). Neoliberalism rose after the realization of challenges that were faced by capitalism (what was then called threats to values of civilization by capitalist historians, economists and philosophers ( as alluded to by Harvey).

The struggle against exploitation is waged internationally. Therefore, there should be a concerted effort from feminist movements to link with other progressive movements to engage the patriarchal capitalist order than to rely on states whose rhetorics are informed by a socialist epistemology and yet grounded on capitalist praxis. It may be further

\footnotetext{
${ }_{1}^{1}$ Paul Volcker was appointed as Chairman of the Federal Reserve Board by President Jimmy Carter in 1965 when the US was experiencing inflation.

${ }^{2}$ According to David Harvey (A brief history of Neo-liberalism,2005), neoliberalism is in the first instancea theory of political economic practices that proposes that human well-being can best be advanced by liberating individual entrepreneurial freedoms and skills within an institutional framework characterized by strong private rights, free markets, and free trade. The role of the state is to create and preserve an institutional framework appropriate to such practices. Neoliberalism has in short, become a hegemonic as a mode of discourse. It has pervasive effects on ways of thought to the point where it has become incorporated into the common sense way many of us interpret,live in, and understand the world. Harvey asserts that the process of neoliberalism has entailed much "creative distruction",not only of prior institutional frameworks and powers, but also of divisions of labour,social relations, and welfare provisions
} 
argued that the plight of women can also be addressed only when there is a dialectical relationship with the fight against patriarchy, misogyny and Capitalism. A genuine discourse based on democracy, egalitarianism, gender equality, amongst others, should be encouraged especially within the ranks of the oppressed and marginalized people.

\subsection{Violence against women in African communities.}

The problem that South Africa is grappling with is the historical dispossession of the indigenous people of their land and the monopolization of the wealth by a few elites. The African majority who have suffered during Apratheid rule and under land dispossession are still angry. This anger ,in most cases, expresses itself in violence. This violence usually is meted out to those who are weaker .And most of these are women. Black women in these communities are therefore urged to exert some type of intellectual leadership. Many feminists in South Africa have lost contact with the yearnings and aspirations of the impoverished women. Within Black communities, there is a need for a strong Black feminist movement that provides the oppressed women with a vision. There is a need for a Black feminist movement that can rise up against the scourge of domestic violence, a movement of Black intellectuals which must aggressively push an anti-patriarchal agenda and the self-definition theme because speaking for oneself and crafting one 's own agenda is important for the empowerment of women.

\section{Conclusion}

A general campaign for the rights of women cannot by itself challenge intersecting oppressions without the struggle to empower women. Self-definition is key to an undivided group empowerment. This is so because women have survived their experiences with intersecting oppressions ( i.e. Racial oppression, Gender oppression and class oppression).The historical resistance to racial and class oppression in the country should propel women to be at the fore-front of the struggle against domestic violence, patriarchy and misogyny.

\section{References}

Ellsberg,M,Heise,L.2001.Researching violence against women, methodological considerations from three Nicaraguan Studies.Studies in Family planning,32-,1-16.

Thobejane,T.D. 2012.South African Journal for Folklore Studies. Volume 22 No.Pp.37-43.

Harvey, D.2007.A brief history of Neo-liberalism. New York. Oxford University Press

Mangena,M. 2013. Let the patriots Stand up.Cape Town.Reach Publishers

Hill Collins, O.2009.Black Feminist Thought. New York. Routledge Publishers

Social Science and Medicine. 2002.Risk factors for domestic violence: Findings from a South African Cross-sectional study.Johannesburg.Pergamon. 